\title{
Dohaekseunggi-tang extract inhibits obesity, hyperlipidemia, and hypertension in high-fat diet-induced obese mice
}

\author{
Yoon-Young Sung ${ }^{1}$, Dong-Seon Kim ${ }^{1}$, Goya Choi ${ }^{1}$, Seung-Hyung Kim² and Ho Kyoung Kim ${ }^{\text {* }}$
}

\begin{abstract}
Background: Dohaekseunggi-tang (DHSGT) is a traditional plant-based medicine prescribed to promote blood circulation and to treat obesity and hypertension. The present study aimed to identify potential anti-obesity activities of DHSGT extract.

Methods: Anti-obesity, anti-hyperlipidemic, and anti-hypertensive effects of orally-administered DHSGT extract were evaluated in high-fat diet- (HFD)-induced obese mice. Serum biochemistry profiles and expression of diverse metabolic regulatory gene mRNAs in mouse visceral fat were assessed by RT-PCR. The effects of DHSGT on angiotensin-1 converting enzyme (ACE) and pancreatic lipase activities were determined using in vitro inhibition assays.

Results: Oral DHSGT treatment reduced obese HFD C57BL/6 J mouse body weight, liver and adipose tissue mass, adipocyte size, and blood pressure versus untreated HFD mice. DHSGT also decreased serum total cholesterol, LDL-cholesterol, triglyceride, glucose, and leptin concentrations, and increased HDL-cholesterol and adiponectin levels in HFD mice. Furthermore, DHSGT markedly increased mRNA expression of peroxisome proliferator activated receptor-gamma, uncoupling protein-2, and adiponectin in visceral adipose tissue of HFD mice. In vitro tests revealed that DHSGT effectively inhibited porcine pancreatic lipase and ACE activities, with $I C_{50}$ values of $7.58 \mathrm{mg} / \mathrm{ml}$ and $0.56 \mathrm{mg} / \mathrm{ml}$, respectively.
\end{abstract}

Conclusions: These results validate traditional knowledge and suggest that DHSGT may be potentially useful for managing hyperlipidemia, hyperglycemia, hypertension, and obesity.

Keywords: Angiotensin-1 converting enzyme, Body weight, Dohaekseunggi-tang, High-fat diet, Pancreatic lipase, Visceral adipose tissue

\section{Background}

Obesity is associated with an imbalance between energy intake and energy expenditure and a subsequent accumulation of excess fat [1]. Obesity is a major risk factor for metabolic diseases such as hyperlipidemia, hypertension, atherosclerosis, type 2 diabetes, and fatty liver [2]. Pharmacological agents such as appetite-suppressants, fat absorption suppressants, and thermogenic drug are often prescribed for weight loss in treating obesity [3]. Orlistat, which reduces dietary fat absorption by inhibiting pancreatic lipase, is currently on the global market [4].

\footnotetext{
* Correspondence: hkkim@kiom.re.kr

'Herbal Medicine Resources Group, Herbal Medicine Research Division, Korea Institute of Oriental Medicine, 1672 Yuseong-daero, Yuseong-gu, Daejeon 305-811, Republic of Korea

Full list of author information is available at the end of the article
}

Pancreatic lipase is a major enzyme involved in triglyceride absorption in the intestine, and inhibiting fat absorption from the diet is a target for treating obesity [5]. However, these drugs have many limitations due to adverse effects, such as stomach pain, steatorrhea, and headaches [6]. Recently, the high prevalence of obesity and associated complications such as hypertension has led to increased research in traditional herbal medicines that have negligible adverse effects, as alternative weightloss therapies [7].

In symptom-based Oriental medicine, the underlying treatment mechanism of obesity is accomplished as follows: remove dampness, dispel phlegm, induce diuresis, remove internal heat, promote digestion and remove food stagnancy, restore the normal flow of the liver Qi (vital energy), 
and invigorate the spleen [8,9]. Dohaekseunggi-tang (DHSGT) (Taohe Chengqi Tang: Chinese), is a traditional medicine prescribed for oral administration to drain heat and promote blood flow to eliminate blood stasis [10]. In Korea, it is mainly prescribed to treat obesity and hypertension caused by stagnation of phlegmdampness and blood stasis [3,11]. DHSGT has also been documented to treat diabetes mellitus, chronic pyelonephritis, chronic hepatitis, acute necrotic enteritis, and amenorrhea [12] .This prescription is an herbal mixture composed of Glycyrrhizae uralensis Fischer (Chinese licorice), Rheum undulatum Linne (a rhubarb relative), Prunus persica L. (peach tree), and Cinnamomum cassia Presl (Chinese cinnamon, an evergreen tree) [13]. Recently, DHSGT was reported to ameliorate diabetic atherosclerosis in western diet-fed apolipoprotein E knockout (ApoE KO) mice [14]. Treatment with DHSGT in western diet-fed ApoE KO mice also reduced LDL cholesterol, triglyceride, and glucose levels as well as blood pressure [14]. In high-fat diet-induced obese rats, DHSGT decreased the body weight, liver and adipose tissue weights, and serum triglyceride levels [15]. DHSGT also decreased plasma glucose, cholesterol, triglyceride, and LDL cholesterol levels in high-fat/high-cholesterol diet-fed $d b / d b$ mice [16]. These results show that DHSGT may be useful in the treatment of obesity and metabolic disease. However, DHSGT effects and mechanisms of action in treating obesity remain obscure. Here, we investigated the potential anti-obesity and anti-hypertensive effects of DHSGT using a high-fat diet-induced mouse model and in vitro assays to evaluate possible DHSGT inhibition of pancreatic lipase and angiotensin-1-converting enzyme (ACE) activities.

\section{Methods}

\section{Preparation of DHSGT}

The herbs were purchased from Kwangmyeongdang Medicinal Herbs Co. (Ulsan, Korea) and authenticated based on their microscopic and macroscopic characteristics by the Classification and Identification Committee of the Korea Institute of Oriental Medicine (KIOM). The formula for DHSGT consists of five herbs including Glycyrrhizae uralensis Fischer (40 g), Rheum undulatum Linne (80 g), Prunus persica Linne (60 g), Cinnamomum cassia Presl (40 g), and Natrii Sulfas (40 g) mixed. The DHSGT $(260 \mathrm{~g})$ was boiled with distilled water $(1: 10, \mathrm{v} / \mathrm{v})$ at $100^{\circ} \mathrm{C}$ for $2 \mathrm{~h}$, and the extract was filtered, lyophilized, and subsequently stored at $-20^{\circ} \mathrm{C}$. The yield of DHSGT aqueous extract was $11.25 \%(\mathrm{w} / \mathrm{w})$.

\section{Animals and experimental diets}

Male, 8-week-old C57BL/6 J mice were purchased from The Jackson Laboratory (Bar Harbor, ME, USA). They were housed in an air-conditioned room with a 12-h light/12-h dark cycle at a temperature of $21 \pm 2^{\circ} \mathrm{C}$ and humidity of $50 \pm 5 \%$, and were fed a commercial diet (Ralston-Purina, St. Louis, MO, USA) for 1 week. Mice were provided with a laboratory diet and water ad libitum. For inducing obesity, the mice were fed a high-fat diet (Rodent Diet D12492; Research Diets, Inc., New Brunswick, NJ, USA), providing $60 \%$ of energy as fat, $20 \%$ as protein, and $20 \%$ as carbohydrates. Non-obese control mice were fed a commercial standard chow diet (Orient Bio Inc., Seongnam, Korea) consisting of 14\% energy as fat, $21 \%$ as protein, and $65 \%$ as carbohydrates. The mice were randomly divided into three groups $(n=5)$, and respectively fed a normal diet (Control), a high-fat diet (HFD) and a high-fat diet plus DHSGT (HFDDHSGT) for 7 weeks. DHSGT was dissolved in normal saline, and was orally administered to the mice (200 mg/kg/day). The Control and HFD mice received vehicle (normal saline) only. Body weight and food intake were monitored every week. This study adhered to the Guide for the Care and Use of Laboratory Animals developed by the Institute of Laboratory Animal Resources of the National Research Council, and was approved by the Institutional Animal Care and Use Committee of Daejeon University in Daejeon, Korea.

\section{Biochemical serum assay}

At the end of the experiment period, the mice were anesthetized with ether after an overnight fast. Blood was withdrawn from the abdominal aorta into a vacuum tube. Biochemical analyses of concentrations of total cholesterol, HDL cholesterol, LDL cholesterol, triglyceride, glucose, creatinine, aspartate aminotransferase (AST), and alanine aminotransferase (ALT) were determined using an automatic analyzer (Express Plus; Chiron Diagnostics, East Walpole, MA, USA). Serum insulin, leptin, and adiponectin levels were measured by immunoassay (ELISA) using commercially available kits (Linco Research Inc., St. Charles, MO, USA).

\section{Weight and histology analysis of adipose tissues and liver} After blood collection, the white adipose tissues (subcutaneous and visceral fat) and liver were removed from each mouse and weighed. For adipocyte staining, visceral adipose tissue was fixed in 10\% neutral-buffered formalin solution for 1 day, paraffin-embedded, sectioned to a thickness of $6 \mu \mathrm{m}$, and stained with hematoxylin and eosin. To quantitate adipocyte size, the stained sections were analyzed using light microscopy (Olympus BX51, Olympus Optical Co., Tokyo, Japan) and image analysis software (Image-Pro Plus version 5.0; Media Cybernetics, Silver Spring, MD, USA). 


\section{Real-time quantitative RT-PCR}

Total RNA from visceral adipose tissue was isolated with TRI reagent ${ }^{\circ}$ (Sigma-Aldrich, St. Louis, MO, USA) and digested with DNase I (Life Technologies, Grand Island, NY, USA) to remove chromosomal DNA. Five micrograms of total RNA was reverse transcribed into cDNA with the First Strand cDNA Synthesis kit (Amersham Pharmacia, Piscataway, NJ, USA). Real-time quantitative PCR was performed using the Applied Biosystems 7500 Real-Time PCR system (Applied Biosystems, Grand Island, NY, USA). The primer sequences and the probe-sequence are shown in Table 1. Probes were labeled with the fluorescent reporter 6-carboxy-fluorescein. Aliquots of sample cDNAs and an equal amount of beta-actin cDNA were amplified with the TaqMan ${ }^{\circ}$ Universal PCR master mixture containing DNA polymerase according to manufacturer instructions (Applied Biosystems, Foster, CA, USA). PCR conditions were $2 \mathrm{~min}$ at $50^{\circ} \mathrm{C}, 10 \mathrm{~min}$ at $95^{\circ} \mathrm{C}, 15 \mathrm{~s}$ at $95^{\circ} \mathrm{C}$, and $1 \mathrm{~min}$ at $60^{\circ} \mathrm{C}$ for 40 cycles. The concentration of target gene was determined using the comparative $\mathrm{Ct}$ (threshold cycle number at cross-point between amplification plot and threshold) method, according to manufacturer instructions.

\section{Blood pressure measurement}

Blood pressure was determined by a tail-cuff method using the CODA ${ }^{\text {tw }}$ noninvasive blood pressure cuff system (Kent Scientific Corp., Torrington, CT, USA).

\section{Pancreatic lipase activity inhibition assay}

The ability of DHSGT to inhibit pancreatic lipase activity was measured using the QuantiChrom ${ }^{\text {Th }}$ lipase assay kit (BioAssay Systems, Hayward, CA, USA). The colorimetric enzyme assay is based on the dimercaptopropanol tributyrate (BALB) and 5,5'-dithiobis 2-nitrobenzoic acid (DTNB) method of Furukawa et al. [17]. DHSGT was dissolved in water and serially diluted. After incubating $10 \mathrm{ul}$ of DHSGT sample solution at different concentrations $(0,0.5,1,2,6.25,12.5$ or $25 \mathrm{mg} / \mathrm{ml})$ or water (control, no inhibition) and $5 \mathrm{ul}$ of porcine pancreatic

Table 1 Sequences of probe and oligonucleotides used in real-time RT-PCR analysis

\begin{tabular}{|c|c|c|}
\hline Genes & $\begin{array}{l}\text { Probe and } \\
\text { Primer }\end{array}$ & Sequence \\
\hline \multirow[t]{2}{*}{ Leptin } & sense & 5'-AACCCTTACTGAACTCAGATTGTTAG-3' \\
\hline & antisense & 5'-TAAGTCAGTTTAAATGCTTAGGG-3' \\
\hline \multirow[t]{2}{*}{ UCP-2 } & sense & 5'-TTCAAATGAGATTGTGGGAAAAT-3' \\
\hline & antisense & 5'-ACCGATACAGTACAGTACAGTA-3' \\
\hline \multirow[t]{2}{*}{ Adiponectin } & sense & 5'-CCCAAGGGAACTTGTGCAGGTTGGATG-3' \\
\hline & antisense & 5'-GTTGGTATCATGGTAGAGAAGAAAGCC-3' \\
\hline PPAR- $\gamma$ & FAM & 5'-TCGGAATCAGCTCTGTGGACCTCTCC-3' \\
\hline GAPDH & $\mathrm{VIC}$ & 5'-TGCATCCTGCACCACCAACTGCTTAG-3' \\
\hline
\end{tabular}

lipase solution (50 units/ml) with $140 \mathrm{ul}$ of working solution for $10 \mathrm{~min}$ and $20 \mathrm{~min}$ at room temperature, sample absorbance was measured at $412 \mathrm{~nm}$ using a microplate reader (Multiskan ${ }^{\circ}$ GO; Thermo Fisher Scientific, Hudson, $\mathrm{NH}$, USA). The working solution was prepared by the addition of $5 \mathrm{mg}$ color DTNB reagent and $8 \mathrm{ul}$ substrate BALB solution (20 mM BALB in ethanol) in $140 \mathrm{ul}$ Tris buffer (100 mM Tris- $\mathrm{HCl}$ and $5 \mathrm{mM} \mathrm{CaCl}_{2}, \mathrm{pH}$ 8.5). Lipase activity was determined by measuring the $\mathrm{SH}$ group formed from lipase cleavage of BALB react with DTNB to yellow colored product. Orlistat $(0,0.01,0.1,0.5$ or $1 \mathrm{mg} / \mathrm{ml}$ ) was used as the positive control. Lipase inhibition (\%) was calculated according the following formula: Inhibition activity $(\%)=\left\{\left[\mathrm{OD}(20 \mathrm{~min}-10 \mathrm{~min})_{\mathrm{control}^{-}} \mathrm{OD}\right.\right.$ (20 min-10 min $\left.)_{\text {sample }}\right] /$ OD (20 min-10 min $\left.)_{\text {control }}\right\} \times 100$. The $\mathrm{IC}_{50}$ value was defined as the concentration of inhibitor required to inhibit $50 \%$ of pancreatic lipase activity.

\section{ACE activity inhibition assay}

ACE activity was measured using the K-assay $\mathrm{ACE}$ inhibition kit (Kamiya Biomedical Co., Seattle, WA, USA). DHSGT was dissolved in water and serially diluted. Twenty $\mu$ of DHSGT sample solution at different concentrations $(0,0.03,0.06,0.125,0.25,0.5,1$ or $2 \mathrm{mg} / \mathrm{ml})$ or water (control, no inhibition) were added to $20 \mu \mathrm{l}$ of $3 \mathrm{HB}$ GGG substrate buffer (0.69 mM 3-hydroxybutyryl-GlyGly-Gly in $50 \mathrm{mM}$ HEPES, pH 8.3). Twenty $\mu$ lof ACE enzyme working solution ( 25 units $/ \mathrm{ml})$ was then added and the mixture was incubated at $37^{\circ} \mathrm{C}$ for $60 \mathrm{~min}$. Then, $200 \mu \mathrm{l}$ of indicator WST (a water soluble tetrazolium dye) solution was added to the reaction mixture and incubated at room temperature for another $10 \mathrm{~min}$. The absorbance at $450 \mathrm{~nm}$ was measured the amount of cleaved 3-hydroxybutyric acid (3HB) from 3HB-GGG using a microplate reader. Captopril at same concentrations was used as positive control. ACE inhibition (\%) was calculated according the following formula: Inhibition activity (\%) = $\left[\left(\mathrm{OD}_{\text {control }}-\mathrm{OD}_{\text {sample }}\right) / \mathrm{OD}_{\text {control }}\right] \times 100$. The $\mathrm{IC}_{50}$ value was defined as the concentration of inhibitor required to inhibit $50 \%$ of ACE activity.

\section{Statistical analysis}

Data were analyzed by one-way analysis of variance followed by Duncan's multiple-range tests. All data are presented as means \pm SE. Significant differences were accepted when the p-value was $<0.05$.

\section{Results}

Changes of body weight, food intake and food efficiency ratio

Body weight, body weight gain, food intake, and food efficiency ratio of the mice fed the HFD with oral treatment of DHSGT for 7 weeks shown in Figure 1A and Table 2. The final body weight of mice fed the HFD was higher 


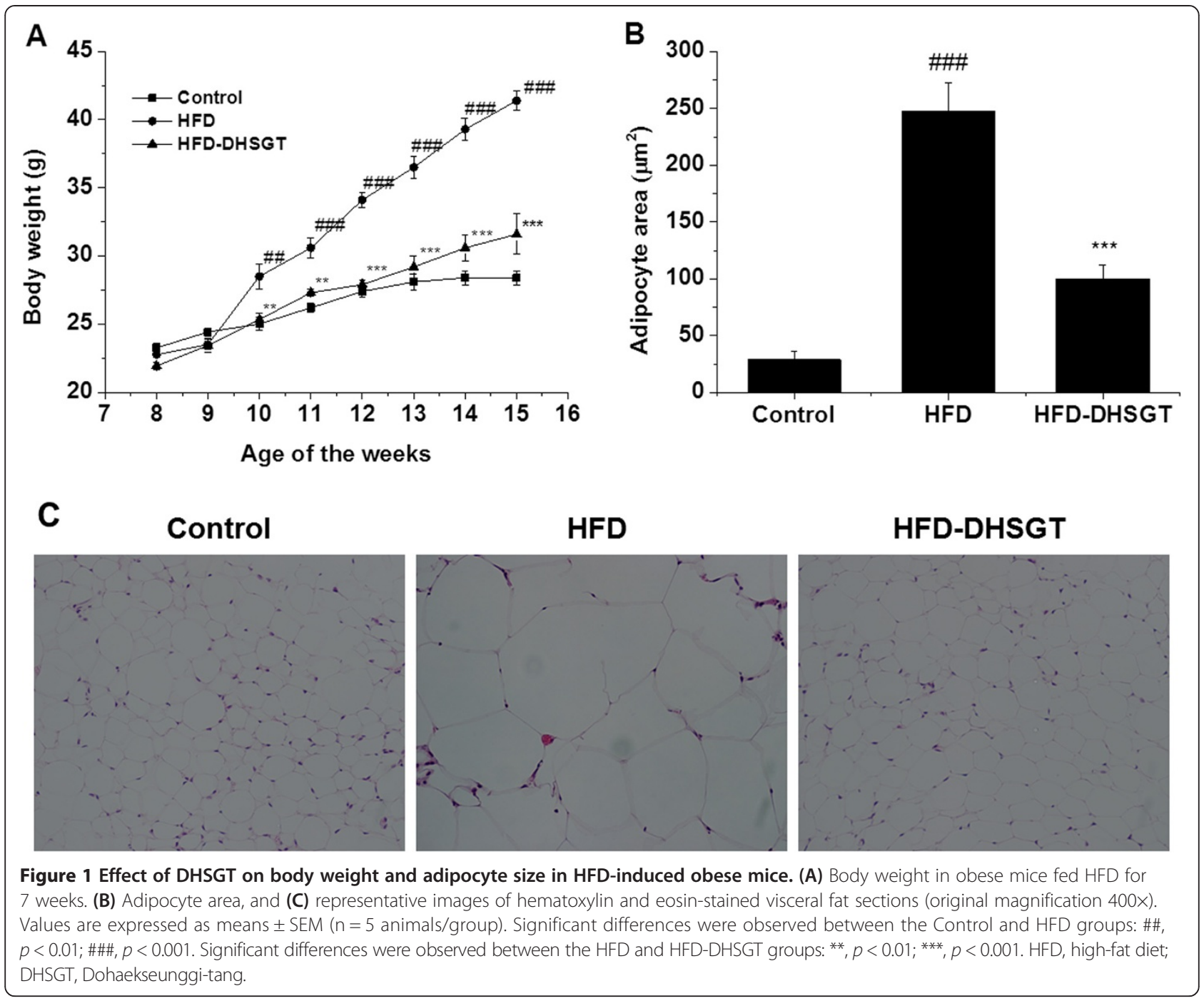

than that of mice fed the normal diet and the DHSGT treatment reduced body weight compared to the high- fat diet group. Body weight gain was significantly decreased in the DHSGT treated group compared to the HFD control group. DHSGT did significantly not affect food intake. Food efficiency ratio (FER) was higher in the HFD group than in the Control group, and the FER was significantly decreased in the DHSGT-treated group versus the HFD group. These results indicate that the DHSGT treatment efficiently reduces body weight increases caused by the high-fat diet.

Table 2 Effects of DHSGT on body weight, food intake, food-efficiency ratio, and tissue weight

\begin{tabular}{|c|c|c|c|}
\hline & Control & HFD & HFD-DHSGT \\
\hline Final body weight, $\mathrm{g}$ & $28.40 \pm 0.51$ & $41.40 \pm 0.68 \# \# \#$ & $31.60 \pm 1.47^{* * *}$ \\
\hline Body-weight gain, g/day & $0.09 \pm 0.01$ & $0.37 \pm 0.02 \# \# \#$ & $0.17 \pm 0.04^{* * *}$ \\
\hline Food intake, g/day & $3.36 \pm 0.00$ & $2.69 \pm 0.00$ & $2.24 \pm 0.00$ \\
\hline Food-efficiency ratio (\%) & $2.64 \pm 0.31$ & $13.60 \pm 0.57 \# \# \#$ & $7.53 \pm 1.58^{* *}$ \\
\hline \multicolumn{4}{|c|}{ White adipose-tissue weight } \\
\hline Subcutaneous, g & $0.29 \pm 0.08$ & $1.92 \pm 0.12 \# \# \#$ & $0.93 \pm 0.45^{* *}$ \\
\hline Visceral, g & $0.28 \pm 0.03$ & $3.79 \pm 0.27 \# \# \#$ & $1.46 \pm 0.30^{* * *}$ \\
\hline Liver weight, g & $1.04 \pm 0.07$ & $1.12 \pm 0.04$ & $0.85 \pm 0.06^{* *}$ \\
\hline
\end{tabular}

Food-efficiency ratio $(\%)=($ body-weight gain/food intake) $\times 100$. Values are expressed as means $\pm \operatorname{SEM}(n=5) ; \# \#, p<0.001$ compared with the Control group; ${ }^{* *} p<0.01 ; * * *, p<0.001$ compared with the HFD group. 


\section{Weights of adipose tissue and liver}

To investigate whether DHSGT decreases adiposity, fat tissues and liver were removed from mice and weighed. Subcutaneous and visceral fat weights were increased in the HFD mice by 6.6 and 13.5-fold, respectively, versus Control mice, and this effect was significantly mitigated by treating HFD mice with DHSGT (Table 2). Liver weight was decreased in the HFD-DHSGT treated mice versus HFD mice (Table 2).

\section{Biochemical determinations in serum}

Serum biochemical profiles of all three mouse groups after receiving their respective diets for 7 weeks are shown in Table 3. The triglyceride, total cholesterol, and LDLcholesterol levels of mice fed the high-fat diet were higher than those of mice fed the normal diet. DHSGT treatment significantly suppressed serum lipid concentration increases in HFD mice. Glucose levels in HFD mice were higher than those of mice fed the normal diet, and DHSGT treatment significantly suppressed HFD-induced serum glucose elevation, to levels approximating those in untreated Control mice. However, HDLcholesterol concentrations were not significantly different between the HFD and HFD-DHSGT groups.

To evaluate potential toxic effects of ingesting DHSGT, serum markers that indicate liver and kidney damage were measured at the end of the experimental period (Table 3). Creatinine levels were significantly decreased in the HFDDHSGT mice versus levels in HFD mice. Serum levels of AST and ALT were increased in HFD mice compared to Control mice. Levels of ALT were significantly decreased in the HFD mice by DHSGT-treatment mice but AST levels were not significantly affected by DHSGT-treatment in HFD mice.

Table 3 Biochemical measurements in mouse serum

\begin{tabular}{lccc}
\hline & Control & HFD & HFD-DHSGT \\
\hline Total cholesterol, mg/dl & $98.6 \pm 3.7$ & $163.2 \pm 13.3 \# \#$ & $130.2 \pm 4.4^{*}$ \\
Triglyceride, mg/dl & $27.0 \pm 1.3$ & $33.4 \pm 1.8 \#$ & $27.4 \pm 1.5^{*}$ \\
LDL cholesterol, mg/dl & $6.4 \pm 0.7$ & $13.8 \pm 1.4 \# \#$ & $7.0 \pm 0.4^{* *}$ \\
HDL cholesterol, mg/dl & $63.0 \pm 0.8$ & $75.0 \pm 2.7 \# \#$ & $69.8 \pm 2.3$ \\
Glucose, mg/dl & $134.8 \pm 3.00$ & $200.2 \pm 11.5 \# \#$ & $144.4 \pm 19.3^{*}$ \\
AST, U/l & $80.8 \pm 4.3$ & $112.6 \pm 10.4 \#$ & $86.8 \pm 5.3$ \\
ALT, U/l & $39.6 \pm 2.4$ & $58.2 \pm 3.7 \# \#$ & $32.0 \pm 3.9^{* *}$ \\
Creatinine, mg/dl & $0.142 \pm 0.015$ & $0.172 \pm 0.009$ & $0.140 \pm 0.008^{*}$ \\
Leptin, ng/ml & $0.14 \pm 0.02$ & $7.35 \pm 0.46 \# \# \#$ & $1.50 \pm 1.12^{* * *}$ \\
Adiponectin, ng/ml & $1.39 \pm 0.24$ & $3.61 \pm 0.29 \# \# \#$ & $13.46 \pm 2.43^{* * *}$ \\
\hline
\end{tabular}

Values are expressed as means \pm SEM $(n=5)$. \#, $p<0.05 ; \# \#, p<0.01 ; \# \#$, $p<0.001$ compared with the Control group; ${ }^{*}, p<0.05 ;{ }^{* *}, p<0.01 ;{ }^{* *}, p<0.01$ compared with the HFD group.

\section{Adipocytokine serum concentrations}

Mice fed the HFD displayed approximately 50-fold increased serum leptin levels versus Control mice (Table 3). Treatment of HFD mice with DHSGT decreased HFDinduced serum leptin by approximately $80 \%$. Serum adiponectin was increased less than 2-fold in HFD mice versus normal-diet Control mice. Treatment of HFD mice with DHSGT caused an additional increase in serum adiponectin, to levels nearly four-fold higher than levels measured in HFD-only mice (Table 3 ).

\section{Histology of adipose tissue}

Average visceral fat adipocyte size (area) in HFD mice was significantly larger (approximately10-fold) than in normal-diet Control mice (Figure 1B and C). When HFD mice were treated with DHSGT, adipocyte size was significantly decreased by over $50 \%$. These results indicate that DHSGT-induced reduction in fat mass was partly due to decreased visceral fat adipocyte size.

\section{Expression of genes involved in lipid metabolism}

To understand the mechanism of DHSGT effects on lipid metabolism, we investigated expression of lipogenesis- or lipolysis-related genes in visceral fat (Figure 2). The HFD increased leptin mRNA expression versus Control mice and DHSGT-treatment decreased HFD-induced leptin mRNA by $>50 \%$ (Figure 2A). While HFD mice expressed similar adiponectin mRNA levels versus Control mice, DHSGT-treatment of HFD mice significantly increased adiponectin (Figure 2B). Peroxisome proliferator activated receptor- $\gamma$ (PPAR- $\gamma)$ mRNA expression was significantly increased in HFD mice versus Control mice, and was further increased by DHSGT-treatment of HFD mice (Figure 2C). Expression of mitochondrial uncoupling protein-2 (UCP-2) mRNA, a molecule involved in fat metabolism, was not affected by HFD alone, but was markedly upregulated in HFD mice that were concomitantly treated with DHSGT (Figure 2D).

\section{Pancreatic lipase inhibition}

The DHSGT extract exhibited pancreatic lipase inhibitory activity in a concentration-dependent manner (Figure 3A). DHSGT at $25 \mathrm{mg} / \mathrm{ml}$ inhibited pancreatic lipase activity by $92.28 \%$, while orlistat ( $1 \mathrm{mg} / \mathrm{ml}$, positive control) inhibited $75.38 \%$ of the enzyme activity (Figure $3 \mathrm{~B}$ ). The $\mathrm{IC}_{50}$ values of DHSGT extract and orlistat were $7.58 \mathrm{mg} / \mathrm{ml}$ and $0.33 \mathrm{mg} / \mathrm{ml}$, respectively.

\section{ACE inhibition}

ACE activity was inhibited by DHSGT extract in a concentration-dependent manner (Figure 4). Two $\mathrm{mg} / \mathrm{ml}$ DHSGT caused 77.06\% inhibition, while $2 \mathrm{mg} / \mathrm{ml}$ captopril (positive control) caused $85.78 \%$ inhibition. The ACE 

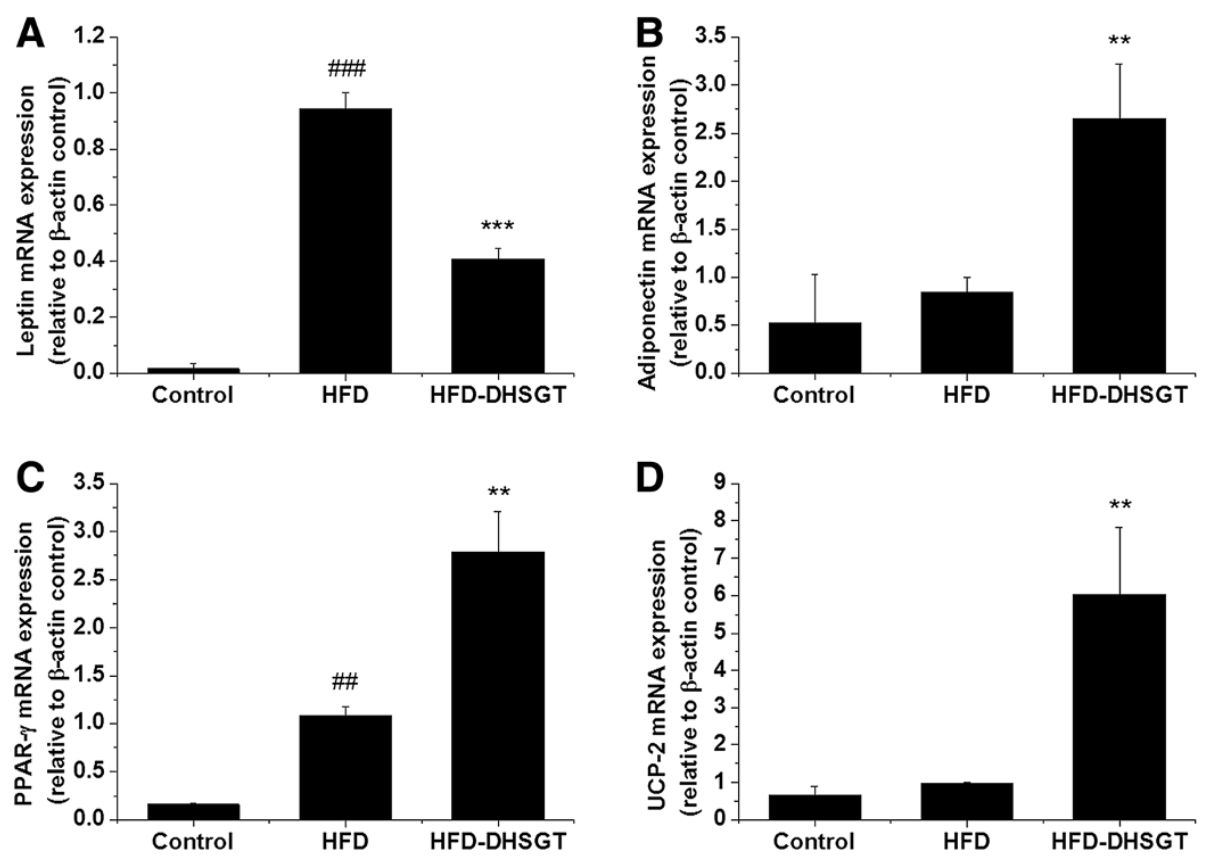

Figure 2 Effect of DHSGT on mRNA expression of leptin, adiponectin, PPAR- $\gamma$, and UCP-2 in visceral adipose tissue of HFD-induced obese mice. Expression levels of (A) leptin, (B) adiponectin, (C) PPAR- $g$, and (D) UCP-2. Values are expressed as means \pm SEM ( $n=5$ animals/group). Significant differences were observed between the Control and HFD groups: \#\#, $p<0.01$; \#\#\#, $p<0.001$. Significant differences were observed between the HFD and HFD-DHSGT groups, respectively: ${ }^{*}, p<0.01$; **, $p<0.001$. DHSGT, Dohaekseunggi-tang; PPAR- $\gamma$, peroxisome proliferator activator receptor- $\gamma$; UCP-2, mitochondrial uncoupling protein-2, HFD, high-fat diet.

inhibition $\mathrm{IC}_{50}$ values of DHSGT extract was $0.56 \mathrm{mg} / \mathrm{ml}$, while captopril had an $\mathrm{IC}_{50}$ value $<0.03 \mathrm{mg} / \mathrm{ml}$ (Figure 4).

\section{Effect of DHSGT on blood pressure}

Systolic, diastolic, and mean blood pressure measurements were all markedly upregulated in HFD mice versus normaldiet control mice (Table 4). All three parameters were significantly decreased in HFD mice that concurrently received DHSGT treatment.

\section{Discussion}

Adipose tissue is a dynamic organ that plays an important role in energy balance and body mass changes throughout an individual's lifetime, in response to the metabolic requirements of the organism [18]. This study investigated the effects of DHSGT on HFD-induced fat accumulation in the adipose tissue of mice. In mice made obese by feeding a high-fat diet, DHSGT treatment inhibited white adipose tissue accumulation and adipocyte enlargement, and, decreased body-weight gain and serum total cholesterol, LDL-cholesterol, triglyceride, and glucose levels.

Adipocytes secrete various adipocytokines such as tumor necrosis factor- $\alpha$, leptin, adiponectin, and resistin [19]. Adiponectin plays important roles in insulin sensitivity and fatty acid oxidation, and adiponectin levels are negatively correlated with body fat mass, and serum glucose, insulin, and triglyceride levels [20]. Leptin levels in human and rodent are directly associated with adiposity and bodyweight changes [21]. In this study, both the serum adiponectin protein levels and adipocyte adiponectin mRNA levels were markedly increased in DHSGT-treated obese mice, whereas leptin expression in serum and adipose tissues was decreased by DHSGT treatment. These results suggest that improved adipocytokines levels by DHSGT treatment may be contribute to decreased body weight, body fat accumulation, and serum levels of glucose, cholesterol, and triglycerides. Obesity due to adipocyte hypertrophy leads to changes in adipocytokine profiles involved in the development of insulin resistance, as well as in the production of signaling molecules, such as PPAR- $\gamma$, aP2, and leptin [22]. PPAR- $\gamma$ is a transcription factor prominently expressed in adipose tissue, and it activates adipocyte differentiation [23]. Moreover, exposure of mice to high fat diet increases adipose tissue expression of PPAR- $\gamma$ [24]. Our result also showed that the HFD-induced obese mice expressed higher mRNA levels of PPAR- $\gamma$ then the normal control mice: however, these effects were weaker than that of the DHSGT-treated mice. In this study, feeding the HFD produced slight increases in serum adiponectin levels. Circulating adiponectin levels were known to be modulated by PPAR- $\gamma$ [25]. Thus, the increases of adiponectin levels in serum of HFD mice may be mediated by the up-regulation of PPAR- $\gamma$. Treatment with DHSGT increased mRNA expression of PPAR- $\gamma$ and UCP- 


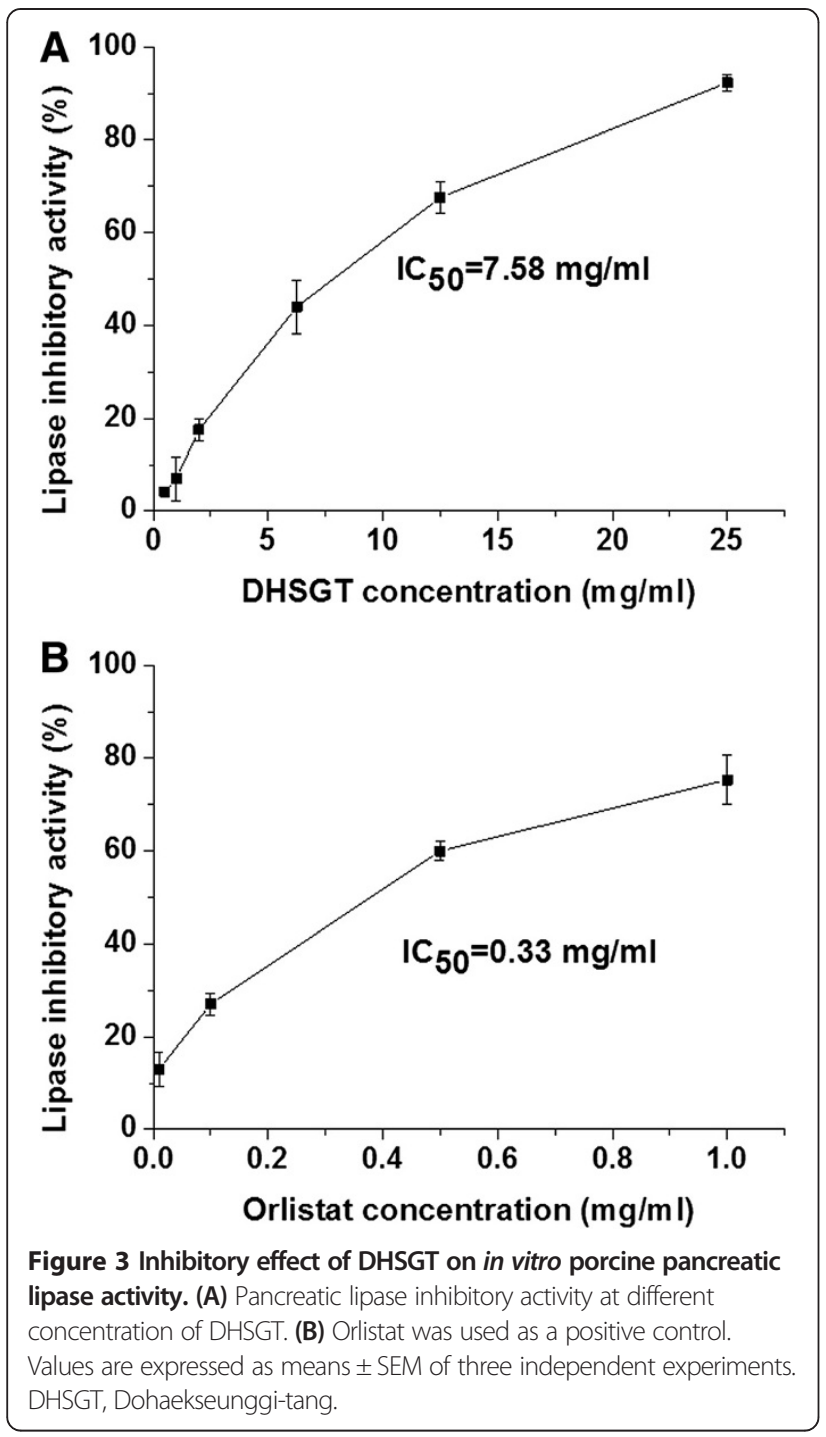

2 in visceral adipose tissue. Thiazolidinediones (TZDs) improve insulin sensitivity through PPAR- $\gamma$, and TZD treatment in obese humans increases adiponectin levels [26]. In rodent disease models, PPARy agonists prevent increased adiposity and body weight, and improve insulin resistance and dyslipidemia [27]. DHSGT treatment restored decreased PPAR- $\gamma$ expression levels in the aorta of western diet-fed ApoE KO mice and the beneficial effect of DHSGT on endothelial dysfunction in diabetic atherosclerosis was similar to rosiglitazone (a PPAR $\gamma$ agonist) which is ameliorated in insulin sensitivity [14]. UCP-2 plays an important role in fat metabolism by promoting fatty acid oxidation in white adipose tissue and reducing body-weight gain [28]. Decreased fat accumulation and serum lipid levels by DHSGT treatment are possibly mediated by increased expression of these regulatory genes.

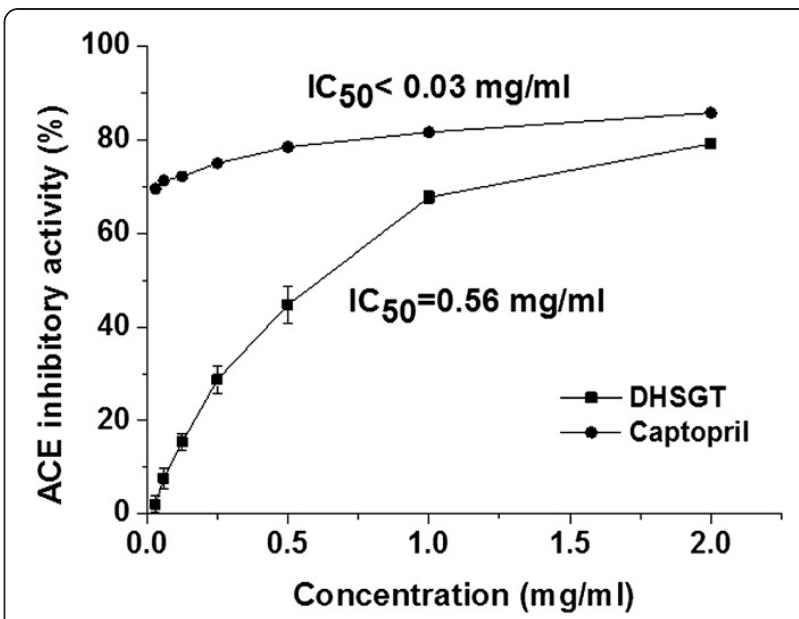

Figure 4 Inhibitory effect of DHSGT on angiotensin 1converting enzyme in vitro. Captopril was used as a positive control. Values are expressed as means \pm SEM of three independent experiments. DHSGT, Dohaekseunggi-tang.

Pancreatic lipase is a key enzyme that hydrolyzes 50$70 \%$ of total dietary fat in the digestive system, converting triglycerides to monoglycerides and free fatty acids $[7,29]$. Inhibiting pancreatic lipase is an important strategy for treating obesity and other metabolic disorders. In this study, DHSGT inhibited pancreatic lipase activity in a concentration-dependent manner, with an $\mathrm{IC}_{50}$ value of $7.58 \mathrm{mg} / \mathrm{ml}$. The lipase inhibitory activity of DHSGT may be able to suppress dietary fat absorption in vivo, too.

Obesity is a worldwide disease that is often accompanied by several metabolic abnormalities such as hypertension, hyperglycemia, and dyslipidemia [30]. The reninangiotensin-aldosterone system (RAAS) is a major mediator of hypertension. The RAAS system produces angiotensin II from angiotensin I, and angiotensinogen via renin and ACE [31]. Additionally, ACE metabolizes and inactivates the vasodilator bradykinin. Thus, ACE has dual roles of increasing vasoconstriction and inactivating vasodilation [32]. DHSGT showed potent inhibitory activity against ACE in vitro, with an $\mathrm{IC}_{50}$ value of $0.56 \mathrm{mg} / \mathrm{ml}$, and it decreased the high blood pressure induced by increasing dietary fat in the HFD mouse group. This indicates a potential anti-hypertensive effect of DHSGT. Activation of the RAAS is common in obesity [33]. Increased

Table 4 Effects of DHSGT on blood pressure

\begin{tabular}{cccc}
\hline & Control & HFD & HFD-DHSGT \\
\hline Blood pressure & & & \\
Systolic, mmHg & $65.36 \pm 6.30$ & $170.56 \pm 06.33 \# \# \#$ & $86.56 \pm 7.39^{* * *}$ \\
Diastolic, mmHg & $61.14 \pm 4.97$ & $167.00 \pm 05.80 \# \# \#$ & $82.33 \pm 7.26^{* * *}$ \\
Mean, mmHg & $62.43 \pm 5.25$ & $101.11 \pm 13.57 \# \# \#$ & $83.67 \pm 7.22^{*}$ \\
\hline
\end{tabular}

Values are expressed as means \pm SEM ( $n=5$ animals per group). \#\#\#, $p<0.001$ compared with the Control group; *, $p<0.05 ;{ }^{* * *}, p<0.001$ compared with the HFD group. 
adipose tissue RAAS activity by diet-induced obesity promotes inflammation, lipogenesis and reactive oxygen species generation, and impairs insulin signaling, all of which worsen the adipose environment [34]. Thus, RAAS pathway blockade by inhibiting ACE activity is one goal in treating the hypertension characteristic of metabolic syndrome and obesity. This study evaluated the ACE inhibitory effects of DHSGT extract using an in vitro model. For natural products to inhibit ACE, they first need to be absorbed in the blood and then act ACE. Since we are evaluating a blend of herbal extracts that contains numerous bioactive compounds, further study is needed to identify and evaluate the active ACE inhibitory compounds in the DHSGT extract.

\section{Conclusions}

DHSGT treatment ameliorates body-weight gain, adipose tissue accumulation, hypertension, and dysregulated serum lipid profiles in HFD-induced obese mice by improving lipid metabolism. Our in vitro assay showed that DHSGT is an effective inhibitor of pancreatic lipase and ACE activity. These findings validate traditional knowledge and suggest that DHSGT may potentially be useful for managing hyperlipidemia, hyperglycemia, hypertension, and obesity. Thus, further study will be performed to identify and characterize the bioactive components responsible for its anti-obesity and anti-hypertensive effects.

\section{Abbreviations}

ACE: Angiotensin-1 converting enzyme; ALT: Alanine aminotransferase; AST: Aspartate aminotransferase; DHSGT: Dohaekseunggi-tang; HDL: High density lipoprotein; LDL: Low density lipoprotein; PPARY: Peroxisome proliferator-activated receptor $\gamma$; RAAS: Renin-angiotensin-aldosterone system; UCP: Uncoupling protein.

\section{Competing interests}

The authors declare that there are no competing interests.

\section{Authors' contributions}

YYS, DSK and HYK participated in the design of the study. YYS carried out the experiments, analyzed the data, and wrote the manuscript. DSK and GC participated in ethnobotanical data collection and prepared the samples. SHK carried out the animal studies. All authors read and approved the final manuscript.

\section{Acknowledgements}

This work was mainly supported by Discovery of Herbal Medicine for Prevention of prehypertension (K13202), the Korea Institute of Oriental Medicine (KIOM) to the Ministry of Science, ICT \& Future Planning (MSIP), Korea. Additionally, this work was also partially supported by Efficacy Study of Alternative Herbal Medicine Resources (K14416), the Korea Institute of Oriental Medicine (KIOM) to the Ministry of Science, ICT \& Future Planning (MSIP), Korea.

\section{Author details}

${ }^{1}$ Herbal Medicine Resources Group, Herbal Medicine Research Division, Korea Institute of Oriental Medicine, 1672 Yuseong-daero, Yuseong-gu, Daejeon 305-811, Republic of Korea. ${ }^{2}$ Institute of Traditional Medicine and Bioscience, Daejeon University, Daejeon 300-716, Republic of Korea.

Received: 29 April 2014 Accepted: 24 September 2014 Published: 4 October 2014

\section{References}

1. Son Y, Nam JS, Jang MK, Jung IA, Cho SI, Jung MH: Antiobesity activity of Vigna nakashimae extract in high-fat diet-induced obesity. Biosci Biotechnol Biochem 2013, 77(2):332-338.

2. Medina-Gomez G, Vidal-Puig A: Gateway to the metabolic syndrome. Nat Med 2005, 11(6):602-603.

3. Song MY, Chung SH, Lee JS, Kim SS, Shin HD: The study on pharmacological treatment of obesity in western and oriental medicine. J Oriental Med 1999, 4(1):55-65.

4. Yun JW: Possible anti-obesity therapeutics form nature-A review. Phytochemisty 2010, 71:1625-1641.

5. Kim YS, Lee Y, Kim J, Sohn E, Kim CS, Lee YM, Jo K, Shin S, Song Y, Kim JH, Kim JS: Inhibitory activities of Cudrania tricuspidata leaves on pancreatic lipase in vitro and lipolysis in vivo. Evid Based Complement Alternat Med 2012, 2012:878365. doi: 10.1155/2012/878365.

6. Filippatos TD, Derdemezis CS, Gazi IF, Nakou ES, Mikhailidis DP, Elisaf MS: Orlistat-associated adverse effects and drug interactions: a critical review. Drug Saf 2008, 31(1):53-65.

7. Birari RB, Bhutani KK: Pancreatic lipase inhibitors from natural sources: unexplored potential. Drug Discov Today 2007, 12(19-20):879-889.

8. Kang YY: Treatment of obesity in Chinese medicine. J Peijing Chin Med Coll 1985, 8:26.

9. Wang WJ: Prevention and treatment of metabolic syndrome with integrated traditional Chinese and western medicine. Zhong Xi Yi Jie He Xue Bao 2004, 2(5):390-395.

10. Lai TY, Weng YJ, Kuo WW, Chen LM, Chung YT, Lin YM, Tsai FJ, Lee CH, Choong YM, Lai EY, Huang CY, Yeh YL: Taohe Chengqi Tang ameliorates acute liver injury induced by carbon tetrachloride in rats. Zhong $X_{i} Y_{i}$ Jie He Xue Bao 2010, 8(1):49-55.

11. Korean Medicine College: Circulation of Oriental Medicine.Neurological Medicine. Korea: Kunja Press; 2010:171-178.

12. Chen Q: Pharmacology and Application of Chinese Herbs. Taiwan: SMC; 1989:451.

13. Kim JB, Choi SH, An KS: Study of the effects of Taorenchengqitang and its components on blood stasis model. Korean J Oriental Physiol Pathol 1997, 11:65-76.

14. Yoon JJ, Lee YJ, Park OJ, Lee SM, Lee YP, Cho NG, Kang DG, Lee HS: Doinseunggitang ameliorates endothelial dysfunction in diabetic atherosclerosis. Evid Based Complement Alternat Med 2013, 2013:783576 doi:10.1155/2013/783576.

15. Jeong $\mathrm{JH}$ : The effects of Dohaeksungitang on the weight and lipid metabolism of induced obesity rats. MA thesis. Hyung Hee University, Department of Oriental Medicine; 1993.

16. Lee YJ, Kin EK, Kim HY, Yoon JJ, Lee SM, Lee GM, Kang DG, Lee HS: Therapeutic effect of Doinseunggi-tang on diabetic vascular dysfunction. Herb Formul Sci 2013, 21(1):119-130.

17. Furukawa I, Kurooka S, Arisue K, Kohda K, Hayashi C: Assays of serum lipase by the "BALB-DTNB method" mechanized for use with discrete and continuous-flow analyzers. Clin Chem 1982, 28(1):110-113.

18. Harp JB: New insights into inhibitors of adipogenesis. Curr Opin Lipidol 2004, 15(3):303-307.

19. Fasshauer $M$, Paschke $R$ : Regulation of adipocytokines and insulin resistance. Diabetologia 2003, 46(12):1594-1603.

20. Arita Y, Kihara S, Ouchi N, Takahashi M, Maeda K, Miyagawa J, Hotta K, Shimomura I, Nakamura T, Miyaoka K, Kuriyama H, Nishida M, Yamashita S, Okubo K, Matsubara K, Muraguchi M, Ohmoto Y, Funahashi T, Matsuzawa Y: Paradoxical decrease of an adipose-specific protein, adiponectin, in obesity. Biochem Biophys Res Commun 1999, 257(1):79-83.

21. Maffei M, Halaas J, Ravussin E, Pratley RE, LeeGH ZY, Fei H, Kim S, Lallone R, Ranganathan S, Lee GH, Zhang Y, Fei H, Kim S, Lallone R, Ranganathan S: Leptin levels in human and rodent: measurement of plasma leptin and ob RNA in obese and weight-reduced subjects. Nat Med 1995, 1(11):1155-1161.

22. Shin SS, Jung YS, Yoon KH, Choi S, Hong Y, Park D, Lee H, Seo BI, Lee HY, Yoon M: The Korean traditional medicine gyeongshingangjeehwan inhibits adipocyte hypertrophy and visceral adipose tissue accumulation by activating PPARalpha actions in rat white adipose tissues. J Ethnopharmacol 2010, 127(1):47-54.

23. Schoonjans K, Staels B, Auwerx J: The peroxisome proliferator activated receptors (PPARs) and their effects on lipid metabolism and adipocyte differentiation. Biochim Biophys Acta 1996, 1302(2):93-109. 
24. Vidal-Puig A1, Jimenez-Liñan M, Lowell BB, Hamann A, Hu E, Spiegelman B, Flier JS, Moller D: Regulation of PPAR gamma gene expression by nutrition and obesity in rodents. J Clin Invest 1996, 97(11):2553-2561.

25. Chandran M, Phillips SA, Ciaraldi T, Henry RR: Adiponectin: more than just another fat cell hormone? Diabetes Care 2003, 26(8):2442-2450.

26. Yu JG, Javorschi S, Hevener AL, Kruszynska YT, Norman RA, Sinha M, Olefsky JM: The effect of thiazolidinediones on plasma adiponectin levels in normal, obese, and type 2 diabetic subjects. Diabetes 2002, 51(10):2968-2974.

27. Kersten S: Peroxisome proliferator activated receptors and obesity. Eur J Pharmacol 2002, 440(2-3):223-234.

28. Andrews ZB, Erion DM, Beiler R, Choi CS, Shulman GI, Horvath TL: Uncoupling protein-2 decreases the lipogenic actions of ghrelin. Endocrinology 2010, 151(5):2078-2086.

29. Lowe ME: Pancreatic triglyceride lipase and colipase: insights into dietary fat digestion. Gastroenterology 1994, 107(5):1524-1536.

30. Mokdad AH, Ford ES, Bowman BA, Dietz WH, Vinicor F, Bales VS, Marks JS: Prevalence of obesity, diabetes, and obesity-related health risk factors. JAMA 2003, 289(1):76-79.

31. Rüster $\mathrm{C}$, Wolf $\mathrm{G}$ : The role of the renin-angiotensin-aldosterone system in obesity-related renal diseases. Semin Nephrol 2013, 33(1):44-53.

32. Xie Y, Zhang W: Antihypertensive activity of Rosa rugosa Thunb. flowers: angiotensin I converting enzyme inhibitor. J Ethnopharmacol 2012, 144(3):562-566.

33. Thethi T, Kamiyama M, Kobori $\mathrm{H}$ : The link between the renin-angiotensinaldosterone system and renal injury in obesity and the metabolic syndrome. Curr Hypertens Rep 2012, 14(2):160-169.

34. Frigolet ME, Torres N, Tovar AR: The renin-angiotensin system in adipose tissue and its metabolic consequences during obesity. J Nutr Biochem 2013, 24(12):2003-2015.

doi:10.1186/1472-6882-14-372

Cite this article as: Sung et al.: Dohaekseunggi-tang extract inhibits obesity, hyperlipidemia, and hypertension in high-fat diet-induced obese mice. BMC Complementary and Alternative Medicine 2014 14:372.

\section{Submit your next manuscript to BioMed Central and take full advantage of:}

- Convenient online submission

- Thorough peer review

- No space constraints or color figure charges

- Immediate publication on acceptance

- Inclusion in PubMed, CAS, Scopus and Google Scholar

- Research which is freely available for redistribution 